J. Appl. Glycosci., 50, 37-39 (2003)

(C) 2003 The Japanese Society of Applied Glycoscience

Note

\title{
Characteristics of Amylose Forming Complexes with Glycerol Monooleate and Monostearate
}

\author{
(Received April 12, 2002; Accepted August 19, 2002) \\ Masatsugu Yamashita, ${ }^{1, *}$ Hideya Adachi, ${ }^{1}$ Takeshi Nakamura, ${ }^{1}$ Hajime Taniguchi, ${ }^{2}$ \\ Satoru Onogi' and Makoto Hisamatsu ${ }^{3}$ \\ ${ }^{1}$ Taiyo Kagaku Central Research Laboratories (1-3, Takara-machi, Yokkaichi, Mie 510-0844, Japan) \\ ${ }^{2}$ Department of Biological Chemistry, Chubu University (1200, Matsumoto-cho, Kasugai, Aichi 487-8501, Japan) \\ ${ }^{3}$ Faculty of Bioresources, Mie University (1515, Kamihama, Tsu, Mie 514-8507, Japan)
}

\begin{abstract}
The formation of amylose complexes with glycerol monooleate (MG-C18:1) or glycerol monostearate (MG-C18:0) was conducted in aqueous solution using a commercial amylose with an average degree of polymerization $(\overline{\mathrm{DP}})$ of 18 . The chain distributions of amylose precipitated by forming a complex in aqueous solution $\left(20^{\circ} \mathrm{C}\right)$ were analyzed by high-performance anion exchange chromatography with a pulsed amperometric detector (HPAEC-PAD). The critical DPs of amylose forming complexes with MG-C18:1 and MG-C18:0 were DP 31 and 29, respectively. The principal chains of amylose forming complexes with MG-C18:1 and MGC18:0 were DP 35-36 and DP 33-34, respectively.
\end{abstract}

Key words: amylose complex, glycerol monooleate, glycerol monostearate, amylose chain-length

The use of fatty-acid monoglyceride to form a complex with starch has been used as a quality improvement agent for anti-firming or food texturing of starch-based foods such as breads and Japanese noodles. The authors have already reported that monoglycerides and lysophospholipids consisting of unsaturated fatty acids could form complexes with amylose and starch in aqueous solutions. ${ }^{1,2)}$

The number of glucosyl residues of amylose required to for form a complex with a saturated fatty acid was estimated with a computer by imaging a state including the fatty acid in amylose as a helical structure, ${ }^{3,4)}$ but the glucosyl residue calculations seemed to be different from the experimental results ${ }^{5-8)}$ obtained using amyloses with different chain lengths.

In this paper, the sizes of amylose required to form complexes with glycerol monostearate or glycerol monooleate were estimated by analyzing chain distributions of the obtained complexes using high-performance anion exchange chromatography with a pulsed amperometric detector (HPAEC-PAD).

\section{MATERIALS AND METHODS}

Materials. Glycerol monostearate (MG-C18:0, purity 99\%) and glycerol monooleate (MG-C18:1, purity 97\%) were purchased from Funakoshi Co., Ltd. (Tokyo, Japan) and Nippon Oil \& Fats Co., Ltd. (Tokyo, Japan), respectively. Amylose EX-1 ( $\overline{\mathrm{DP}} 18$; crude protein, $0.02 \%$; moisture, $7.90 \%$ ) was purchased from Hayashibara Biochemical Laboratories (Okayama, Japan). Methanol, dimethyl sulfoxide (DMSO), potassium hydroxide (KOH) and hydrochloric acid $(\mathrm{HCl})$ were purchased as specialgrade materials from Wako Pure Chemical Industries Co., Ltd. (Osaka, Japan). Sodium hydroxide $(\mathrm{NaOH})$ and so-

* Corresponding author (Tel. +81-593-47-5402, Fax. +81-59347-5417, E-mail: myamashita@taiyokagaku.co.jp). dium acetate $\left(\mathrm{CH}_{3} \mathrm{COONa}\right)$ were purchased as HPLCgrade materials from Wako Pure Chemical Industries Co., Ltd.

Preparation of $0.2 \%(w / v)$ amylose solution. Amylose EX-1 (2.0 g) dispersed in distilled water $(100 \mathrm{~mL})$ was mixed with $1 \mathrm{M} \mathrm{KOH}(100 \mathrm{~mL})$ and then stirred continuously for $60 \mathrm{~min}$ at $4^{\circ} \mathrm{C}$. After adjusting the $\mathrm{pH}$ to 6.0 with $1 \mathrm{M} \mathrm{HCl}$, the amylose solution was diluted with distilled water to $1000 \mathrm{~mL}$.

Preparation of a complex of lipid and amylose. After dissolving MG-C18:0 (50 mg) or MG-C18:1 (50 mg) in methanol $(5 \mathrm{~mL})$, both lipid solutions were dispersed in distilled water $(45 \mathrm{~mL})$ and stirred continuously for 30 min at $70^{\circ} \mathrm{C}$, respectively. After cooling to $60^{\circ} \mathrm{C}$, both monoglyceride solutions were mixed with $250 \mathrm{~mL}$ of $0.2 \%(\mathrm{w} / \mathrm{v})$ amylose solution, respectively, and then stirred occasionally for $30 \mathrm{~min}$ at $60^{\circ} \mathrm{C}$. After cooling, the mixtures were kept at $20^{\circ} \mathrm{C}$ for $3 \mathrm{~h}$ to complete the inclusion complexes, and then centrifuged at $15,000 \times g$ for 20 $\min$ at $20^{\circ} \mathrm{C}$.

After the supernatant was decanted carefully, the precipitate obtained was resuspended in distilled water (200 $\mathrm{mL})$ at $20^{\circ} \mathrm{C}$ and then centrifuged $\left(15,000 \times g, 20^{\circ} \mathrm{C}, 20\right.$ $\mathrm{min}$ ) in order to rinse the inclusion complex. This process was conducted twice and the pure inclusion complex (A) was lyophilized.

Preparation of amylose contributed to complex formation. The inclusion complex $(10 \mathrm{mg})$ was dissolved in DMSO $(1 \mathrm{~mL})$, mixed with methanol $(50 \mathrm{~mL})$ and centrifuged at $15,000 \times g$ for $20 \mathrm{~min}$ at $10^{\circ} \mathrm{C}$. The precipitate (B) obtained was rinsed with methanol and then lypophilized.

Differential scanning calorimetry. Sample A (5 mg) of MG-C18:0 and MG-C18:1 was weighed on a DSC silver pan $(70 \mu \mathrm{L})$ with distilled water $(20 \mathrm{mg})$ and the pan was hermetically sealed immediately to prevent moisture loss. The endothermic peak was determined by measuring 
with a differential scanning calorimeter (DSC-100, Seiko Instruments Inc., Tokyo, Japan) at a heating rate of $1{ }^{\circ} \mathrm{C} /$ min. The onset temperature $\left(T_{0}\right)$ and peak temperature $\left(T_{\mathrm{p}}\right)$ of sample A of MG-C18:0 and MG-C18:1 were measured to characterize the thermal property of complex.

HPAEC-PAD analysis. Sample B (1.0 mg) was dissolved in $1 \mathrm{M} \mathrm{NaOH}(100 \mu \mathrm{L})$, diluted with distilled water $(300 \mu \mathrm{L})$ and then centrifuged at $3000 \mathrm{rpm}$ at room temperature. The supernatant $(50 \mu \mathrm{L})$ was subjected to HPAEC-PAD analysis using a Dionex BioLC system (Dionex Co., Sunnyvale, CA, USA) with a pulsed amperometric detector (Model PAD II) and a CarboPac PA1 column (250×4 mm I.D.). Eluent A was $150 \mathrm{~mm} \mathrm{NaOH}$ and eluent B was $150 \mathrm{mM} \mathrm{NaOH}$ containing $500 \mathrm{~mm}$ $\mathrm{CH}_{3} \mathrm{COONa}$. The gradient program was as follows: \% of eluent $\mathrm{B}, 10$ at $0 \mathrm{~min}, 80$ at $80 \mathrm{~min}$ and 100 at $87 \mathrm{~min}$, respectively.

\section{RESULTS AND DISCUSSION}

\section{Preparation of a lipid and amylose complex.}

The complexes of Amylose EX-1 ( $\overline{\mathrm{DP}} 18$ ) with monoglycerides did not precipitate at $60^{\circ} \mathrm{C}$, but crystalline precipitate appeared at $20^{\circ} \mathrm{C}$. The inclusion complexes (A) obtained with MG-C18:0 and MG-C18:1 were 51.5 and $42.6 \mathrm{mg}$, respectively. These results indicate that the complex-forming ability of MG-C18:1 toward amylose is somewhat lower than that of MG-C18:0.

\section{Differential scanning calorimetry.}

Many reports have been published on the DSC curve of amylose-lipid complex as proof of complex formaton. ${ }^{1,2,8-10)}$ The endothermic peak on the DSC curve of the inclusion complex (A) with MG-C18:0 was observed at $59.3\left(T_{0}\right)$ and $62.0^{\circ} \mathrm{C}\left(T_{\mathrm{p}}\right)$, and the dissolution enthalpy change $(\Delta H)$ was $9.6 \mathrm{~J} / \mathrm{g}$ (Fig. $1 \mathrm{~B}$ ). The endothermic peak on the curve of the inclusion complex (A) with MG-C18:1

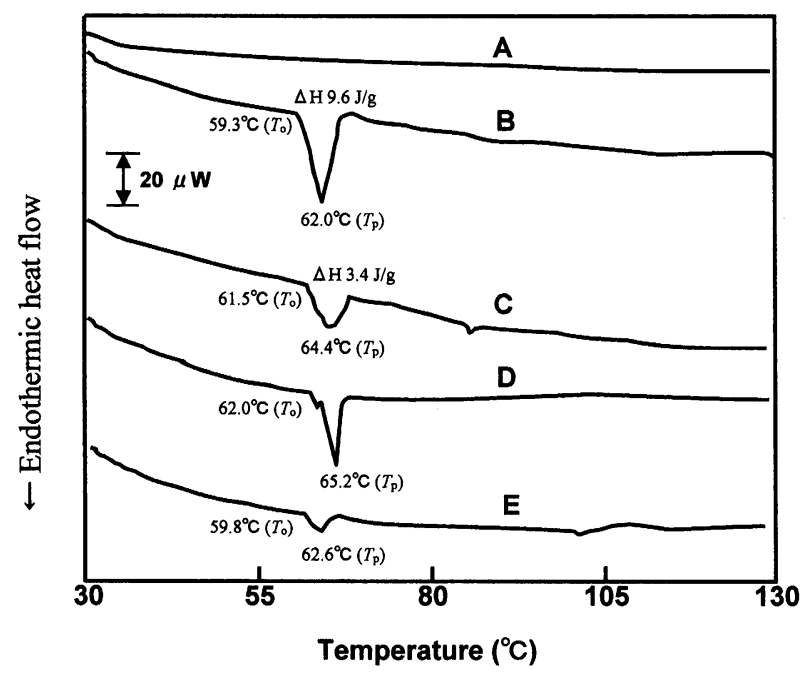

Fig. 1. DSC thermograms of Amylose EX-1, amylose-MG-C18:0 complex, amylose-MG-C18:1 complex, MG-C18:0 and MG-C18:1 with the addition of water (sample, $5 \mathrm{mg}$; water, $20 \mathrm{mg}$; heating rate, $1^{\circ} \mathrm{C} / \mathrm{min}$ ).

A, Amylose EX-1; B, amylose-MG-C18:0 complex; C, amyloseMG-C18:1 complex; D, MG-C18:0; E, MG-C18:1. To, onset temperature; $T_{\mathrm{p}}$, peak temperature. was observed at $61.5\left(T_{\mathrm{o}}\right)$ and $64.4^{\circ} \mathrm{C}\left(T_{\mathrm{p}}\right)$, and the $\Delta H$ was $3.4 \mathrm{~J} / \mathrm{g}$ (Fig. $1 \mathrm{C}$ ). The temperatures of these peaks are clearly different from the temperatures of MGs (Fig. 1 $\mathrm{D}, \mathrm{E})$. The endothermic peak on the curve of Amylose EX-1 alone was not observed (Fig. 1 A). From these results, the occurrence of complexes between the monoglycerides and Amylose EX-1 could be confirmed.

\section{HPAEC-PAD analysis.}

The chain-length distribution of Amylose EX-1 is shown in Fig. 2, which is in good agreement with the results of Koizumi et al ${ }^{11)}$ The chain-length distributions of amyloses recovered from the inclusion complexes with the monoglycerides were analyzed by HPAEC-PAD (Fig. 3). The difference in chain-length distribution between the MG-C18:0 precipitate and that of MG-C18:1 is shown in Fig. 4.

The amylose chain profiles recovered from complexes are quite different from that of Amylose EX-1. The critical DP of amylose recovered from the complex with MGC18:0 was estimated to be DP 29, and the principal chain was DP 33-34. The critical DP of amylose recovered from the complex with MG-C18:1 was estimated to be

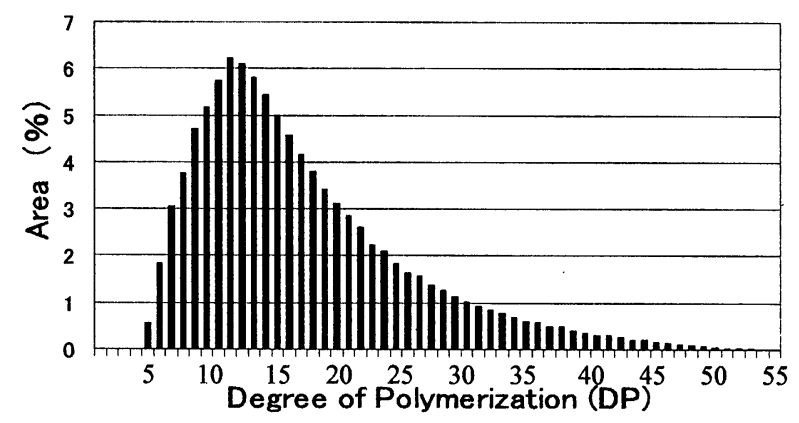

Fig. 2. HPAEC-PAD analysis of Amylose EX-1.
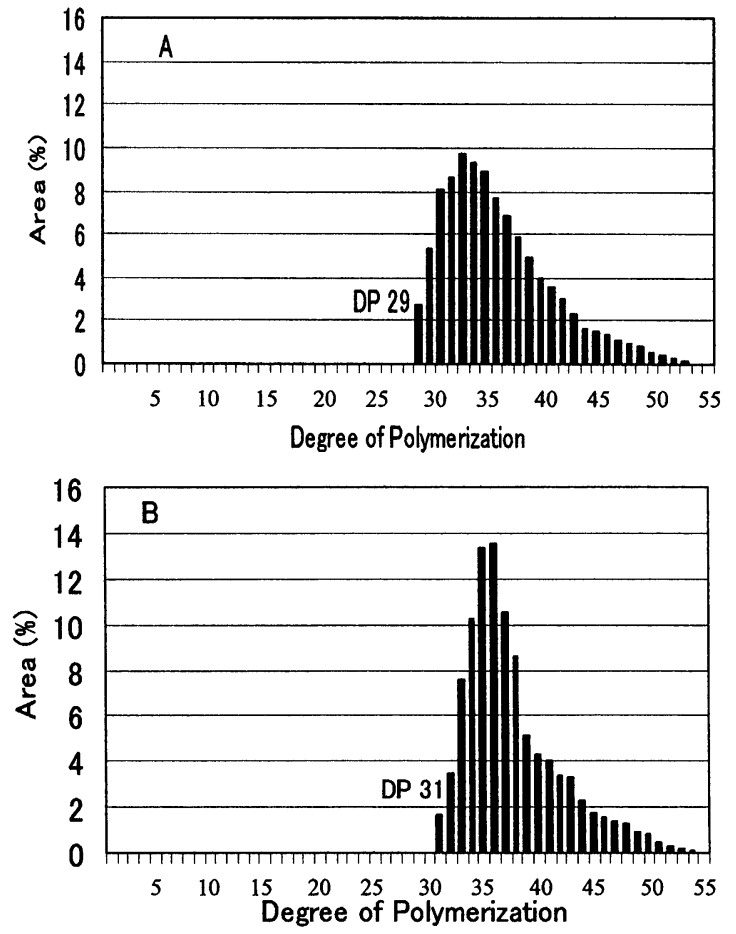

Fig. 3. HPAEC-PAD analyses of the amyloses in the precipitates formed by complexes using MG-C18:0 (A) and MGC18:1 (B). 


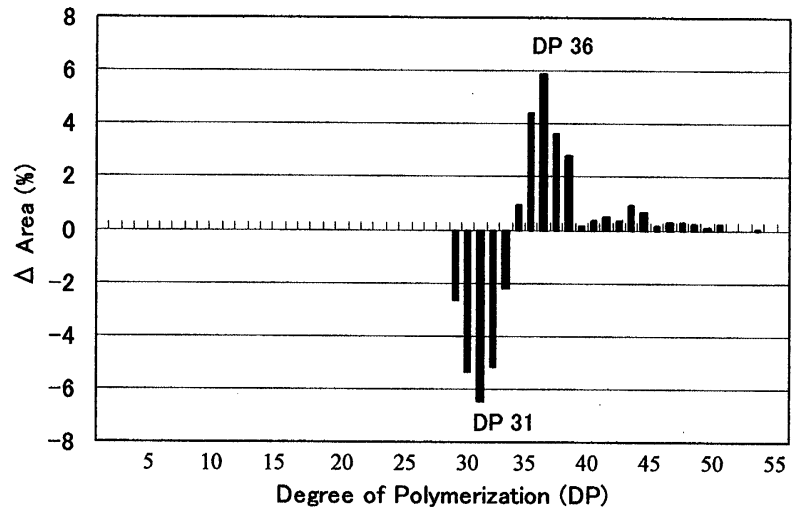

Fig. 4. The differences in chain numbers calculated by subtracting the value of MG-C18:0 precipitate from that of MGC18:1 precipitate.

DP 31, and the principal chain was DP 35-36. From a comparison of the chain-length distribution of the two complexes, it was found to be obvious that the inclusion complex with MG-C18:1 was composed of longer amylose chains than the inclusion complex with MG-C18:0, as shown in Fig. 4. Amylose chains found in the complex with MG-C18:1 are about 2-5 glycosyl residues longer than those found in the complex with MG-C18:0. It is presumed that the helical structure of amylose including oleic acid in MG-C18:1 needs 2-5 more glucose residues because of the bent structure of the double bond in the fatty acid.

As the amylose used in this study was $\overline{\mathrm{DP}} 18$, the content of amylose fractions longer than DP 29 was extremely low. A study on the inclusion complex of many fatty acids should be conducted using longer amylose chains like $\overline{\mathrm{DP}} 30$.

\section{REFERENCES}

1 ) M. Yamashita, H. Adachi, T. Nakamura and N. Tokuriki: Starch complexing capacities of polyhydric alcohol esters of unsaturated fatty acids. Nippon Shokuhin Kagaku Kogaku Kaishi, 47, 112-119 (2000).

2 ) M. Yamashita, H. Adachi and N. Tokuriki: Starch complexing capacity of soy lysophospholipid prepared by enzyme hydrolysis. Nippon Nogeikagaku Kaishi, 74, 19-25 (2000).

3 ) A. Neszmély, E. László and J. Holló : Biomolecular modelling: An interactive program for the visualization and modelling of carbohydrate (starch and oligosaccharide) complexes in solution. Starch:Stärke, 39, 393-396 (1987).

4 ) M.C. Godet, V. Tran, M.M. Delage and A. Buleon: Molecular modelling of the specific interactions involved in the amylose complexation by fatty acids. Int. J. Biol. Macromol., 15, 11-16 (1993).

5 ) J. Lagendijk and H.J. Pennings: Relation between complex formation of starch with monoglycerides and the firmness of bread. Cereal Sci. Today, 15, 354-365 (1970).

6 ) J. Karkalas and S. Raphaelides: Quantitative aspects of amylose-lipid interaction. Carbohydr. Res., 157, 215-234 (1986).

7 ) M.C. Godet, A. Buleon, V. Tran and P. Colonna: Structural features of fatty acid-amylose complexes. Carbohydr. Polym., 21, 91-95 (1993)

8 ) M.C. Godet, H. Bizot and A. Buleon: Crystallization of amylose-fatty acid complexes prepared with different amylose chain lengths. Carbohydr. Polym., 27, 47-52 (1995).

9 ) S. Raphaelides and J. Karkala: Thermal dissociation of amylose-fatty acid complexes. Carbohydr. Res., 172, 65-82 (1988).
10) A.C. Eliasson and N. Krog: Physical properties of amylosemonoglyceride complexes. J. Cereal Sci., 3, 239-248 (1985).

11) K. Koizumi, T. Utamura and Y. Okada: Analysis of homogeneous D-gluco-oligosaccharides and -polysaccharides (degree of polymerization up to about 35 ) by high-performance liquid chromatography and thin-layer chromatography. J. Chromatogr., 321, 145-157 (1985).

\section{オレイン酸モノグリセリドおよびステアリン酸}

モノグリセリドと複合体を形成するアミロースの特性

山下政続 ${ }^{1}$, 足立秀哉1, 中村武嗣1, 谷口 肇 ${ }^{2}$ 小野木 悟 ${ }^{3}$, 久松 葚 $^{3}$

1 太陽化学株式会社総合研究所

（510-0844 三重県四日市市宝町 1-3）

2 中部大学応用生物学部

（487-8501 愛知県春日井市松本町 1200）

3 三重大学生物資源学部

（514-8507 三重県津市上浜町 1515）

オレイン酸モノグリセリド（MG-C18:1）およびステア リン酸モノグリセリド（MG-C18:0）と平均重合度 18 の アミロースを用いて, 水溶液で複合体を調製した. $20^{\circ} \mathrm{C}$ で沈澱した複合体について，そのアミロース鎖長を HPEAC-PAD で分析した. MG-C18:1 およびMG-C18:0の 複合体を形成し始めるアミロース鎖長は, それぞれDP 31，DP 29 であった.また, MG-C18:1 および MG-C18:0の 複合体を構成する主なアミロース鎖長は, それぞれDP 3536, DP 33-34であった。 